\title{
Pappalimbang di Muara Sungai Tangka Tahun 1998-2016
}

\author{
Muazzinul Hair, Saleh Madjid, Amirullah \\ Prodi Pendidikan Sejarah Fakultas Ilmu Sosial Universitas Negeri Makassar, Indonesia \\ hmuazzinul@gmail.com, salehmadjid@unm.ac.id,amirullah8505@unm.ac.id
}

\begin{abstract}
Abstrak
Tulisan ini membahas mengenai pappalimbang di Muara Sungai Tangka tahun 1998-2016 yang akan terurai dalam beberapa submateri yaitu latar belakang adanya Pappalimbang di Muara Sungai Tangka, perkembangan Pappalimbang di Muara Sungai Tangka, dan kehidupan sosial ekonomi Pappalimbang di Muara Sungai Tangka. Masalah yang dikaji dalam tulisan ini adalah pappalimbang di Muara Sungai Tangka yang ke Laggoppo Desa Massangkae yang digunakan oleh masyarakat Laggoppo Desa Massangkae untuk ke Kabupaten Sinjai. Penelitian ini bersifat deskfiptif analisis dengan menggunakan metode historis. Melalui tahapan-tahapan, Heuristik dengan menemukan sumber-sumber yang berkaitan dengan penelitian, baik itu berupa buku, jurnal, dan mengunjungi lokasi penelitian dan melakukan wawancara yang ada kaitannya dengan penelitian ini. Melalui kritik, baik itu kritik internal maupun kritik ekstern untuk didapatkan fakta sejarah mengenai pappalimbang di Muara Sungai Tangka. dari fakta tersebut kemudian diinterpretasikan secara kronologis dan kemudian di sajikan dalam suatu tulisan sejarah. Hasil penelitian menunjukkan bahwa adanya pappalimbang di Muara Sungai Tangka tidak terlepas dari kebutuhan masyarakat Desa Massangkae khususnya di Dusun Laggoppo I dan Laggoppo II, tempat tinggal mereka yang masih tertinggal sehingga mereka mencari tempat yang lebih maju untuk beraktivitas. Adapun perkembangan pappalimbang dapat dilihat dari penggunaan transportasinya, dimana yang sebelumnya menggunakan sampang dengan tenaga manusia sekarang sudah menggunakan perahu motor. Sementara kehidupan Sosial-ekonomi pappalimbang selalu berinteaksi dengan masyarakat dan tolong menolong antar pappalimbang, serta membantu penumpangnya. penghasilan mereka tidak menentu tergantung pada banyaknya penumpang yang mereka dapatkan.
\end{abstract}

\section{Kata Kunci: Pappalimbang, Sungai Tangka}

\begin{abstract}
This paper discusses the pappalimbang at the Tangka River Estuary in 1998-2016 which will be broken down in several submissions, namely the background of the Pappalimbang in the Tangka River Estuary, the development of Pappalimbang in the Tangka River Estuary, and the social economic life of the Pappalimbang in the Tangka River Estuary. The problem examined in this paper is the pappalimbang in the Tangka River estuary to Laggoppo Massangkae Village used by the Laggoppo community in Massangkae Village to Sinjai Regency. This research is descriptive analysis using historical methods. Through the stages, Heuristics by finding sources related to research, whether in the form of books, journals, and visiting research locations and conducting interviews that are related to this research. Through criticism, both internal criticism and external criticism to obtain historical facts about pappalimbang in the Tangka River Estuary. of these facts are then interpreted chronologically and then presented in a historical writing. The results showed that the existence of a pappalimbang at the Tangka River Estuary was inseparable from the needs of the people of Massangkae Village, especially in Laggoppo I and Laggoppo II hamlets, where those who were still left behind were looking for a more advanced place to move. The development of pappalimbang can be seen from the use of transportation, where those who previously used sampang with human labor have now used motorboats. While the socio-economic life of the pappalimbang always interacts with the
\end{abstract}


community and helps help between the pappalimbang, and helps the passengers. their income is uncertain depending on the number of passengers they get.

\section{Keywords: Pappalimbang, Sungai Tangka}

\section{A. Pendahuluan}

Negara-negara yang sedang berkembang, masalah sektor informal sebenarnya menjadi semakin penting keberadaannya, namun kondisinya sangat penting. Keberadaanya sangat penting apalagi setelah ekonomi indonesia dirundung krisis seperti sekarang ini, dimana permintaan angkatan kerja di sektor informal ini makin besar seiring dengan siklus usaha sektor formal yang tidak berjalan normal. Kondisi perekonomian seperti sekarang ini mengakibatkan sektor formal kikir dalam menerima pasokan tenaga kerja. Bahkan berpeluang besar dalam memPHK tenaga kerjanya, sehingga sektor informallah yang menjadi tumpuan dan harapan bagi mereka di masa datang. (Mulyadi S, 2014)

Transportasi secara Umum dapat diartikan sebagai usaha pemindahan atau penggerakan orang atau barang dari suatu lokasi, yang disebut lokasi asal ke lokasi lain, yang biasa disebut lokasi tujuan. Untuk keperluan tertentu dengan menggunakan alat tertentu pula. (Fidel Miro. 2016)

Konsepsi penyeberangan adalah sebagai penghubung dan atau alternatif jaringan jalan yang dipisahkan oleh perairan, merupakan wujud pelaksanaan kebijakan pemerintah dibidang transportasi. Sungai, danau dan selat adalah prasarana yang penting bagi lalu lintas dan perkembangan lalu lintas di Indonesia. Selama beberapa ratus tahun yang lalu, angkutan ini tumbuh dan berkembang secara alamiah tanpa dibina. (Herry Gunawan, 2014)

Salah satu pekerjaan sektor informal bidang jasa penyeberangan sungai adalah pappalimbang. Pappalimbang merupakan jasa penyedia penyeberangan dengan menggunakan perahu sebagai transportasinya. Keberadaan pappalimbang sangat membantu masyarakat yang tinggal di sekitaran muara sungai khususnya masyarakat Laggoppo Desa Massangkae dalam menunjang rutinitas kesehariannya.

Pappalimbang di Muara Sungai Tangka menjadi salah satu alternatif masyarakat Desa Massangkae khususnya di Dusun Laggoppo I dan Laggoppo II Kabupaten Bone ke Kabupaten Sinjai. Masyarakat memilih jasa penyeberangan ini dengan alasan jarak tempuh yang dekat dibandingkan dengan jalan darat yang harus mereka tempuh hingga beberapa kilometer untuk sampai di Kabupaten Sinjai.

Kajian yang relevan dengan penelitian ini yaitu karya Mochtar Mandala Putra dalam sebuah skripsi pada tahun 2013. Jurusan Sosiologi Fakultas Ilmu Sosial . Dengan judul Komunitas Tukang Becak di Kel. Mandala Kec. Mamajang Makassar. Pada skripsi tersebut dibahasakan bahwa latar belakang ekonomi menyebabkan warga masyarakat marginal hanya mengandalkan kekuatan fisik sebagai modal utama untuk mencari nafkah. Tukang becak dapat dikatakan dibawah garis kemiskinan, karena hanya mampu untuk memenuhi kebutuhan dasarnya secara minimal tetapi belum mampu untuk memenuhi kebutuhan sosial pshikologinya. Tenaga yang mereka gunakan tidak sebanding dengan yang mereka dapatkan setiap harinya

Selain itu ada pula dalam bentuk tesis yaitu karya Ridwan pada tahun 2015, Program Pascasarjana, Universitas Negeri Makassar. Dengan judul Solidaritas Komunitas Penarik Becak Jeneponto di Kabupaten Maros. Pada pembahasannya Ridwan memfokuskan kajiannya pada kehidupan sosial-ekonomi tukang becak jeneponto yang ada di maros. Dimana dalam penulisannya dijelaskan bahwa angkutan becak digunakan sebagai sarana transportasi alternatif. Selain itu becak dijadikan sebagai mata pencaharian hidup, 
karena becak dianggap bisa menghasilkan uang dengan cepat dan tidak memerlukan keahlian khusus.

Dari kedua kajian relevan yang penulis ambil memiliki persamaan dan perbedaan. Dari penelitian tersebut kajiannya sama yaitu pekerjaan disektor informal dan kedua kajian tersebut merupakan jasa penyedia penumpang serta penghasilannya yang bergantung pada banyaknya penumpang yang mereka dapatkan. Untuk penelitian yang dilakukan oleh penulis fokus pada jasa penyeberangan perahu pappalimbang di Muara Sungai Tangka.

\section{B. Metode Penelitian}

Penelitian ini menggunakan metode penelitian sejarah yang terdiri atas empat tahap, yaitu heurustik (mencari dan mengumpulkan sumber), metode pengumpulan data dilakukan melalui studi pustaka dan penelitian lapangan dengan observasi dan wawancara. Penulis melakukan wawancara dengan

Pappalimbang yang sudah lama menggeluti profesi ini antara lain yaitu bapak Tare, bapak Kahar, bapak Haya, bapak Ramang, dan bapak Abri. Adapun papalimbang yang belakangan yaitu bapak Appa, bapak, Hasta, bapak Zainuddin, bapak Hamid, bapak Amin, bapak Syukri, dan bapak Waris. Selanjutnya, penulis melakukan kritik, kritik intern dan kritik ekstern. Interpretasi (penafsiran sumber) dan Historiografi (penulisan sejarah).

\section{Tinjauan Penelitian}

\section{Kondisi Geografis}

Dusun Laggoppo merupakan dusun di Desa Massangkae, Kecamatan Kajuara, Kabupaten Bone. Dusun Laggoppo Desa Massangkae berbatasan dengan Desa Mallahe di Utara, Buareng di Barat, Teluk Bone di Timur, dan Kelurahan Lappa Kabupaten Sinjai di Selatan. Dusun Laggoppo Desa Massangkae dengan Kabupaten Sinjai sangat dekat, kedua wilayah ini hanya dibatasi oleh muara sungai yaitu Sungai Tangka dan wilayah ini termasuk salah satu wilayah yang cukup jauh dari ibukota Kabupaten Bone. hal ini yang menjadi alasan masyarakat Laggoppo melakukan aktivitas kesehariannya di Kabupaten Sinjai.

Desa Massangkae merupakan desa dengan luas wilayah yaitu $6,00 \mathrm{Km}^{2}$ dengan jarak dari ibukot kecamatan yaitu $6 \mathrm{Km}^{2}$, jarak dari ibukota kabupaten yaitu $76 \mathrm{Km}^{2}$, dan tinggi dari permukaan laut yaitu $<500$. (Badan Pusat Statistik Kabupaten Bone, 2015). Ada empat Dusun di Desa Massangkae yaitu Dusun Laggoppo I, Laggoppo II, Hulo, dan Ellue. Dusun Laggoppo II adalah dusun terluas dengan luas wilayah yaitu 41,8 $\mathrm{Ha}$, sedangkan dusun terkecil yaitu Dusun Ellue yang hanya memiliki luas wilayah yaitu 27.0 Ha. (Kantor Desa Massangkae, 2016).

Desa Massangkae hanya terdapat 2 sekolah dengan 71 murid laki-laki dan 49 murid perempuan dan 11 guru PNS dan 7 guru Non PNS. Satu sekolah terletak di Dusun Laggoppo dan satu sekolah terletak di Dusun Hulo. Sedangkan desa-desa lainnya sulit untuk diakses dan transportasi yang minim (Amirullah, 2017). Hal ini yang menjadi salah satu alasan masyarakat di Desa Massangkae khususnya di Dusun Laggoppo I dan Laggoppo II menempuh pendidikan di Kabupaten Sinjai. (BPS Kabupaten Bone, 2016)

Desa Massangkae tidak ada pasar baik itu pasar umum maupun pasar hewan, serta didesa tersebut tidak ada tempat pelelangan ikan. Begitupun dengan desa terdekat dari Desa Massangkae yaitu Desa Mallahae juga tidak terdapat pasar. Di Kecamatan Kajuara, desa yang memiliki pasar yaitu Desa Raja, Abbumpungeng, Awang Tangka, Bulu Tanah, Lappa Bose, dan Tarasu. Hal ini juga menjadi salah satu alasan masyarakat Desa Massangkae khususnya di Dusun Laggoppo I dan Laggoppo II memilih Kabupaten Sinjai untuk berjualan dan berbelanja, apalagi di Kabupaten Sinjai terdapat PPI Lappa (pusat pendaratan ikan). (BPS Kabupaten Bone, 2016)

Desa Massangkae fasilitas kesehatan masyarakat hanya ada posyandu sedangkan 
rumah sakit, puskesmas, rumah sakit bersalin tidak ada. Begitupun dengan desa sekitarnya hanya ada posyandu. Di Kecamatan Kajuara sama sekali tidak memilki fasilitas kesehatan yang memadai seperti rumah sakit, yang ada hanya posyandu yang terdapat di Desa Raja, Abbumpungeng, Awang Tangka, Bulu Tanah, Kalero, Lappa Bosse, dan Tarasu. Hal ini menjadi alasan masyarakat Desa Massangkae khususnya di Dusun Laggoppo I dan Laggoppo II memilih Kabupaten Sinjai. (BPS Kabupaten Bone, 2016)

\section{Keadaan Demografi}

Demografi merupakan istilah yang terdiri dari dua suku katadari bahasa yunani yaitu demos dan grafein. Kata demos berarti rakyat atau penduduk dan kata grafein berarti menggambar, menulis atau uraian. Dengan demikian, secara singkat "demografi" berarti tulisan atau uraian mengenai penduduk dengan segala aktivitasnya. (Eko Siswanto, 2015). Sebuah data dari BPS Kabupaten Bone tahun 2016 menunjukkan jumlah penduduk di Desa Massangkae yaitu 2.557 jiwa. Terdiri dari 1.280 laki-laki dan 1277 perempuan. jumlah penduduk perempuan lebih banyak dibandingkan jumlah penduduk laki-laki. Dimana jumlah perempuan sebanyak 18.663 dibandingkan dengan laki-laki yang hanya 17.772 orang. (Badan Pusat Statistik, 2016).

Mata pencaharian penduduk Laggoppo Desa Massangkae dapat dibedakan menjadi dua bagian, yaitu bermata pencaharian dan tidak bermata pencaharian. 1.337 orang atau $85.21 \%$ penduduk bermata pencaharian, sedangkan yang tidak bermata pencaharian sebanyak 321 orang atau 14.79\%. Mata pencaharian penduduk Laggoppo kebanyakan bergelut pada sektor informal dan memanfaatkan sumber daya alam tempat bermukimnya. (Kantor Desa Massangkae, 2016).

\section{Pembahasan \\ 1. Awal Mula Munculnya Pappalimbang di Muara Sungai Tangka}

Kebutuhan akan jasa transportasi timbul disebabkan oleh karena tempattempat beraktivitas orang-orang yang melakukan perjalanan tersebar secara spasial sebagai akibat dari kebijakan tata ruang suatu lingkup wilayah (lokal, kota, regional, nasional), yang disebut dengan land use planning. (Fidel Miro, 2005).

Pappalimbang di Muara Sungai Tangka muncul tidak terlepas dari kebutuhan dan permintaan masyarakat Desa Massangkae khususnya di Dusun Laggoppo I dan Laggoppo II. Kebutuhan dan permintaan masyarakat Laggoppo Desa Massangkae disebabkan oleh letak geografis, dimana letak tempat tinggal mereka yang jauh dari pusat kota Kabupaten Bone (Amirullah, 2017). pappalimbang menjadi solusi atas kendala tersebut. Di Laggoppo Desa Massangkae, pappalimbang menjadi pilihan masyarakat untuk menjangkau Kabupaten Sinjai yang bagi mereka merupakan sentral ekonomi, pendidikan, dan kesehatan.

Awalnya pappalimbang di Muara Sungai Tangka bukanlah sebuah profesi atau jasa penyeberangan melainkan hanya sebuah solusi atas kebutuhan masyarakat sekitar. Masyarakat pada waktu itu menggunakan perahu sampang, dan bagi yang tidak memiliki perahu mereka menumpang atau meminta tolong kepada yang punya perahu. Karena sampang membutuhkan tenaga untuk mendayung dan memakan waktu yang lama serta sungai yang bertambah luas sehingga muncullah inovasi untuk menggunakan perahu motor. Penggunaan perahu motor merupakan awal pappalimbang menjadi profesi atau jasa penyeberangan karena perahu memerlukan bahan bakar sebagai penggerak mesin perahu.

Pappalimbang menjadi sebuah profesi berawal ketika pappalimbang menggunakan perahu motor pertama kali untuk penyeberangan. Awalnya perahu yang digunakan yaitu perahu jarangka dengan Mesin yang digunakan pada perahunya 
masih menggunakan mesin sitta merek honda. Perahunyapun waktu itu ukuranya masih kecil sehingga harus memiliki penyeimbang atau masyarakat sekitar menyebutnya dengan istilah hatti. Setelah menggunakan perahu jarangka mereka kemudian beralih ke perahu katinting, perbedaan perahu katinting dengan perahu jarangka hanya pada ukuran badan perahunya yang lebih besar dan sudah tidak menggunakan penyeimbang atau hatti. Mesin yang digunakan sama yaitu mesin sitta merek Honda. Tarif pappalimbang sekarang dengan yang dulupun berbeda, dimana yang dulunya hanya Rp.500, kemudian Rp. 1.000 dan sekarang sudah Rp.2000. (Bapak Kahar, 12 Oktober 2018).

Dengan kemajuan teknologi muncullah inovasi baru yaitu mulai diperkenalkannya mesin diesel merek yanmar. Pappalimbang yang pertama kali menggunakan mesin diesel merek yanmar yaitu bapak Muha dan bapak Lawuhe. menurutnya beliau menggunakan mesin diesel ini agar lebih praktis, cepat, dan perahunyapun ukuranya lebih besar sehingga bisa memuat banyak orang dan dapat digunakan ke Pulau Sembilan. Pappalimbang lainnyapun mengikuti jejak bapak Muha dan Lawuhe yang sudah lebih dulu mengunakannya. (Bapak Haya, 12 Oktober 2018).

Dari data Dinas Perhubungan Laut Kabupaten Sinjai, jumlah perahu pappalimbang yang ke Laggoppo Desa Massangkae ada 17 buah. (Bapak Fajar, 15 Oktober 2018). Dari 17 perahu pappalimbang ke Laggoppo Desa Massangkae, mereka semuanya meminjam uang di bank sebagai modal untuk mengeluti pekerjaan ini. Uang yang mereka pinjam di bank digunakan untuk membeli perahu dan adapula yang hanya membeli kayu nanti mereka yang membuatnya menjadi perahu.

Tiap masyarakat manusia memiliki sistem ekonomi dan sistem mata pencaharian hidup yang spesifik, sesuai dengan spesifikasi kebudayaan dan keadaan potensi sumber daya yang tersedia pada alam sekeliling dimana masyarakat itu sendiri bertempat tinggal, sekaligus menata dasar-dasar kehidupan mereka sebagai suatu kesatuan sosial ekonomi dan Kultural. ( Muh Yunus Hafid, dkk, 1996).

Selain dengan adanya kebutuhan masyarakat, munculnya pappalimbang di Muara Sungai Tangka juga dipengaruhi oleh faktor geografis. Dimana Muara Sungai Tangka berbatasan langsung antara Laggoppo Desa Massangkae Kabupaten Bone dengan Kelurahan Lappa Kec. Sinjai Utara. Pappalimbang memanfaatkan kondisi geografis ini untuk mendapatkan pekerjaan.

Permintaan akan jasa transportasi dari penumpang atau orang timbul oleh akibat kebutuhan orang yang melakukan perjalanan dari suatu lokasi ke lokasi lainnya dalam rangka beraktivitas seperti bekerja, sekolah, belanja, dan lain sebagainnya. (Fidel Miro, 2005).

Masyarakat Laggoppo Desa Massangkae Kabupaten Bone yang sangat jauh dari pusat Kota Kabupaten Bone memilih Kabupaten Sinjai sebagai tempat mereka beraktvitas. Masyarakat Laggoppo Desa Massangkae Kabupaten Bone menjadikan Sungai Tangka sebagai jalur alternatif ke Kabupaten Sinjai. Masyarakat Laggoppo Desa Massangkae Kabupaten Bone memilih transportasi papplimbang dengan alasan jarak tempuh yang dekat dibandingkan jalur darat. Selain juga murah, keberadaan pappalimbang bisa menghemat waktu dan tenaga.

Seperti yang dikatakan oleh Ibu Reni yang berjualan di Pasar Sentral Sinjai. menurut beliau termasuk murah karna Cuma Rp.2.000. dari pada lewat Tobunne, jauh sekali. (Ibu Reni, 20 Oktober 2018). Dikatakan oleh Agus seorang siswa SMP Negeri 3 Sinjai bahwa dia menggunakan pappalimbang karena merupakan jalan alternatif untuk kesekolahnya meskipun harus sambung lagi mobil pete-pete. Pemilihan transportasi pappalimbang oleh anak sekolah selain karena jarak tempuh menjadi dekat, menggunakan pappalimbang lebih cepat untuk sampai ke sekolahnya. (Agus, 20 Oktober 2018). 
Yang memotivasi pappalimbang untuk mengeluti profesi ini yaitu untuk bertahan hidup. Pappalimbang menjadikan pekerjaan ini sebagai modal untuk menyambung hidup karena adanya dan banyaknya kebutuhan hidup yang harus dipenuhi. Adanya kebutuhan baik itu untuk dirinya sendiri, keluarga, maupun untuk anak mereka. Selain itu, alasan lainnya yaitu mereka merasa tidak enak dan jenuh apabila mengganggur. Tentunya mereka menjadikan profesi pappalimbang sebagai suatu profesi akibat dari tidak adanya lapangan pekerjaan yang disediakan untuk pendidikan rendah dan ketatnya persaingan. Alasan lain mereka sehingga menjadi pappalimbang yaitu pekerjaan ini tidak terlalu berat dan santai kerjanya.

Pendidikan rendah, kurangnya keahlian, dan ketatnya persaingan, maka tidak sedikit orang untuk melakukan apapun untuk mendapatkan pekerjaan diluar dari ketiga kriteria tersebut, Semua karena untuk menghidupi keluarganya. Demikian pula dengan pappalimbang sebagai pekerjaan yang tidak membutuhkan keahlian khusus, sekolah tinggi, dan masing-masing bisa menjadi pappalimbang yang jelas mereka mampu untuk mengemudikan perahu.

Selain alasan pendidikan yang rendah sehingga mereka mengeluti profesi pappalimbang, adapula pappalimbang yang dulunya berprofesi sebagai nelayan, mereka rata-rata nelayan pa'meng dan pa'gae. Berbagai alasan mereka beralih profesi dari nelayan menjadi pappalimbang, ada yang memilih menjadi pappalimbang disebabkan faktor usia yang sudah tidak mampu lagi untuk melaut, ada dengan alasan penghasilan melaut tidak menentu dan jauh dari keluarga, dan adapula dengan alasan akibat telah menggunakan alat tangkap terlarang sehingga perahunya tidak diperbolehkan lagi melaut.

\section{Perkembangan Pappalimbang di Muara}

\section{Sungai Tangka}

Pentingnya sarana transportasi dalam perkembangan dunia bersifat multidimensi. Sebagai contoh, salah satu fungsi dasar transportasi adalah menghubungkan tempat kediaman dengan tempat bekerja atau para pembuat barang dengan para pelanggannya. Dari sudut pandang yang lebih luas, fasilitas transportasi memberikan aneka pilihan menuju ketempat kerja, pasar, dan sarana rekreasi, serta menyediakan akses ke sarana-sarana kesehatan pendidikan, dan sarana lainnya. (C. Jotin Khisty, B Kent Lall, 2003)

Transportasi sebagai sarana yang di gunakan pappalimbang untuk mengangkut penumpang dari Laggoppo Desa Massangkae ke Kabupaten Sinjai telah memberikan dampak yang sangat bermanfaat bagi masyarakat Laggoppo Desa Massangkae. Transportasi yang digunakan oleh pappalimbang yaitu perahu. Perahu yang awalnya hanya menggunakan tenaga manusia kemudian beralih seiring dengan perkembangan ilmu pengetahuan dan teknologi, pappalimbang telah menggunakan perahu motor.

Ada empat jenis perahu yang telah digunakan oleh pappalimbang di Muara Sungai Tangka, perahu yang awalnya hanya menggunakan tenaga manusia atau yang disebut sampang, kemudian beralih kepenggunaan perahu motor. Setelah, pappalimbang mengenal mesin, sudah ada tiga jenis perahu motor yang digunakan yaitu jarangka, katinting, dan jolloro. Untuk sekarang ini perahu yang digunakan oleh pappalimbang yaitu jolloro. .

Penggunaan perahu motor oleh pappalimbang di Muara Sungai Tangka muncul sekitar tahun 1970-an. Namun perahu motor yang diguanakan pada waktu itu masih perahu jarangka kemudian sekitar tahun 1980-an beralih kepenggunaan katinting. Meskipun, pada waktu itu masih ada yang menggunakan jarangka. Perahu motor yang sekarang digunakan oleh pappalimbang yaitu jolloro, yang tentunya kualitas mesinnya jauh lebih baik ketimpang jarangka dan katinting. 
Perahu motor pertama yang digunakan oleh pappalimbang sekitar tahun 70-an yaitu jarangka, perahu ini terbuat kayu yang berukuran panjang 6-7 $\mathrm{m}$ dan memiliki lebar 60-70 cm dilengkapi dengan penyeimbang yang terbuat dari pipa atau kayu namun umumnya terbuat dari kayu berbentuk bundar dengan ukuran 8 inchi dan diameter $6 \mathrm{~cm}$ dan dilengkapi dengan mesin Honda atau orang sekitar menyebutnya mesin sitta yang pakai bensin dengan kekuatan 5,5 $\mathrm{Pk}$, mesin ini belum dapat jalan mundur, Untuk jumlah muatannya satu sampai dua orang.

Kemudian jenis perahu yang digunakan oleh pappalimbang sekitar tahun 80-an yaitu katinting, perahu ini terbuat dari kayu berukuran 8 meter agar besar dibandingkan dengan jarangka sehingga tidak memerlukan lagi menggunakan penyeimbang atau hatti. Mesin yang digunakan pada perahu ini sama dengan mesin yang digunakan pada perahu jarangka yaitu mesin Honda yang menggunakan bahan bakar bensin atau premium dengan kekuatan $5,5 \mathrm{Pk}$, mesin ini belum dapat jalan mundur, Untuk jumlah muatannya dua sampai lima orang.

Perahu motor yang sekarang digunakan oleh pappalimbang yaitu jolloro, perahu ini terbuat dari kayu berukuran panjang sekitar 9-11 meter dan lebar badan perahu sekitar $80 \mathrm{~cm}-1$ meter. Perahu ini menggunakan mesin diesel merek yanmar sebagai tenaga penggerak dan solar sebagai bahan bakarnya, mesin ini mempunyai kekuatan jelajah berdasarkan ukuran pk (paardekracht) antara 16 dan 24 pk, umumnya kebanyakan menggunakan 24 pk. Mesin motor ini umumnya menggunakan bahan bakar solar dan kapasitas tangki bahan bakar sebanyak 3 sampai 5 liter. Pada perahu ini terdapat beberapa beberapa bagian yaitu bodi kapal yang terdiri dari bagian belakang, tengah, dan kepala (haluan), serta ditambah kanopi untuk melindungi dari pancaran sinar matahari, hujan, dan embun di waktu malam. Perahu ini dapat memuat 10 orang penumpan beserta barang bawaannya. Umumnya barang bawaan yaitu ikan seember dan kebutuhan-kebutuhan pokok. (Bapak Ramang, 20 Oktober 2018).

Perahu jolloro digunakan oleh pappalimbang sekitar tahun 1998 hal ini Seperti yang diungkapkan oleh bapak Ramang salah satu pappalimbang di Muara Sungai Tangka, beliau mengatakan bahwa, sejak dia bekerja sebagai pappalimbang dia sudah menggunakan perahu motor jenis jolloro. Beliau sendiri sudah bekerja selama 20 tahun. Beliau mengatakan bahwa perahu motor jolloro sudah mulai digunakan pappalimbang sekitar tahun 1998. namun pada waktu itu belum semuanya menggunakann jenis perahu ini. Setelah pappalimbang mengetahui mesin tersebut dan kelebihan-kelebihannya mereka kemudian beralih menggunakan mesin diesel merek yanmar tersebut. (Bapak Ramang, 20 Oktober 2018).

Menurut bapak kahar, beliau mengatakan bahwa sudah lama sekali dia menjadi pappalimbang. dia lupa sudah berapa lama menggeluti profesi ini, bahkan dia pernah menggunakan perahu katinting dan bahkan masih mendapati pappalimbang yang memakai perahu jarangka. yang beliau ingat yaitu masih kecil Wahyudi (salah satu teman yang saya ajak ketika melakukan wawancara dan sekarang berumur 23 tahun) beliau sejak itu sudah menggunakan perahu jolloro. (Bapak Kahar, 12 Oktober 2018)

Perkembangan transportasi perahu oleh pappalimbang tersebut disamping disumbang oleh kreasi internal juga oleh adopsi inovasi dari luar. Dimana keterbatasan-keterbatasan perahu yang mereka gunakan sebelumnya yang menjadi kendala kemudian mereka mencari solusinya agar lebih efektif dan efisien. Mereka melihat pula dari perkembangan 
yang ada disekitarnya yang sudah lebih dulu mengalami kemajuan.

Perahu motor yang digunakan oleh pappalimbang di Muara Sungai Tangka tidak terlepas dari pengaruh perahu motor yang digunakan oleh nelayan dan pappalimbang yang ke Kec. Pulau Sembilan yang berada di Dermaga Cappa Ujung. Jadi, ada dua pappalimbang di Muara Sungai Tangka. Satu yang ke Laggoppo Desa Massangkae Kabupaten Bone, dan satunya lagi yang ke Kec. Pulau Sembilan Kabupaten Sinjai. Nelayan dan pappalimbang ke Pulan Sembilan yang kemudian memperkenalkan perahu motor oleh pappalimbang yang ke Laggoppo Desa Massangkae Kabupaten Bone.

Dampak dari penggunaan perahu motor pappalimbang di Muara Sungai Tangka, memberikan dampak positif baik oleh masyarakat maupun terhadap pappalimbang itu sendiri. Dimana dengan penggunaan perahu motor tercipta suasana aman, nyaman, dan meminimalisir waktu serta kepraktisan dalam bekerja bagi pappalimbang. Dengan menggunakan perahu motor juga meningkatkan penghasilan pappalimbang. Selain itu, dengan perahu motor masyarakat juga lebih efektif dalam bekerja.

Dengan adanya modernisasi pada pappalimbang mempengaruhi masyarakat Laggoppo untuk mengeluti profesi ini, dikarenakan oleh kemudahan dan penghasilannyapun tinggi dibandingkan sebelumnya. Dilihat pula dari faktor pendukung seperti sarana dermaga Cappa Ujung dan PPI Lappa serta makin banyaknya masyarakat Laggoppo Desa Masangkae yang ingin meningkatkan status sosialnya dengan menyekolahkan anaknya ketingkat yang lebih tinggi dan ibu-ibu yang sebelumnya hanya sebagai ibu rumah tangga yang bermukim di Laggoppo kini kian meningkat membantu suaminya mencari penghasilan dengan berjualan di PPI Lappa Kabupaten Sinjai. Faktor-faktor ini lah yang menjadikan pappalimbang jumlahnya meningkat dari sebelumnya. Hal lain yang membuktikan bahwa jumlah pappalimbang meningkat yaitu sudah tidak ditemukannya lagi nelayan yang tidak melaut, bekerja sampingan menjadi pappalimbang dengan alasan bahwa jumlah pappalimbang sudah banyak sehingga mereka sulit untuk mendapatkan penumpang.

Pola kerja pappalimbang umumnya seperti angkutan umum atau ojek pangkalan. Dimana mereka menunggu penumpang yang ingin diantar kesuatu tempat yang ingin dituju. Mereka menunggu penumpang di pinggir Muara Sungai Tangka yang dekat dengan Laggoppo Desa Massangkae Kabupaten Bone dan di Dermaga Cappa Ujung. Penumpang mereka mulai anak sekolah, Mahasiswa/i kerja kantoran, berobat, masyarakat Laggoppo hingga masyarakat Bojo yang ingin berbelanja atau berjualan di Kabupaten Sinjai

Ada dua jenis pappalimbang ke Laggoppo Desa Massangkae, pertama pappalimbang kerja santai dan kedua pappalimbang kerja keras. Pappalimbang jenis pertama yaitu pekerja santai, mereka yang hanya mengisi waktu karena merasa tidak enak kalau tinggal dirumah saja. Pappalimbang jenis ini beroperasi semaumaunya dan berhenti beroperasi ketika sudah ada pembeli rokok. Pappalimbang jenis kedua yaitu pappalimbang pekerja keras, Pappalimbang ini beroperasi mulai subuh sampai larut malam.

Seperti yang diungkapkan oleh bapak Kahar, pappalimbang pekerja santai. Dia semau-maunya bekerja, merasa bosan dan tidak enak juga kalau dirumah terus, kalau sudah ada pembeli rokok dan gula beliau sudah pulang. Biasanya kalau sudah mengantar langganannya beliau sudah naik, Kalau mau kerja diwaktu sore dia turun lagi. (Bapak Kahar, 12 Oktober 2018) 
Sedangkan bapak Abri pappalimbang kerja keras, beliau mengatakan bahwa dia bekerja mulai sudah salat subuh sampai malam. Dia gunakan penghasilan dari pappalimbangnya untuk kebutuhan keluarga dan sekolah anak. Dia sisihkan juga untuk bayar cicilan bank

Pappalimbang umumnya mulai bekerja setelah sholat shubuh, biasanya mereka mengangkut masyarakat Laggoppo Desa Massangkae yang ingin berjualan di PPI Lappa (pusat pendaratan ikan). Penumpang mereka yaitu para penjual ikan dan kue yang berjualan di sekitar PPI Lappa. setelah mengangkut para penjual ikan dan kue, mereka kemudian mengangkut anak sekolah. Setelah itu pappalimbang mulai mengangkut masyarakat yang ingin berbelanja dan pekerja di Kabupaten Sinjai, baik itu pekerja formal maupun yang informal. Setelah dari mengangkut masyarakat dan pekerja di Kabupaten Sinjai , mereka menunggu di dermaga atau di PPI Lappa dan kalau tidak ada mereka menyusuri sungai dari PPI Lappa hingga ke Pelabuhan Cappa Ujung mencari penumpang. Selain mengangkut penumpang, pappalimbang juga menerima pengangkutan barang, masyarakat Kabupaten Sinjai yang memiliki keluarga di Laggoppo Desa Massangkae biasanya menitipkan keluarganya beras atau bahanbahan pokok. Ada juga yang tidak menyeberang hanya menyuruh pappalimbang untuk mengambil barang titipannya ke orang yang sudah menunggu setelah sebelumnya sudah janjian melalui handphone.

Dimalam hari, kebanyakan pappalimbang mangkal di PPI Lappa. penumpang pappalimbang di malam hari yaitu masyarakat Laggoppo Desa Massangkae yang berjualan ikan di PPI Lappa dan masyarakat yang ingin beli ikan di PPI Lappa. Selain itu, masyarakat Desa Awang Tangka kadang ke PPI Lappa pada malam hari beli ikan. Karna biasanya kapal nelayan datang pada malam hari sehingga masyarakat Laggoppo dan masyarakat Desa Awang Tangka pergi ke PPI Lappa di malam hari. Masyarakat Desa Awang Tangka yang ke Kabupaten Sinjai rata-rata mereka penjual ikan di Pasar Bojo Kabupaten Bone.

Pengguna jasa pappalimbang dimalam hari ada pula masyarakat sekitar, baik itu masyarakat dari Sinjai maupun masyarakat Laggoppo dan didominasi oleh anak muda, keperluannya berbeda-beda ada urusan keluarga, urusan kerja, urusan sekolah, silaturahmi dengan temannya dan urusanurusan lainnya. Dimalam hari juga ada beberapa penjual ikan yang menyewa pappalimbang untuk beli es balok di pabrik es yang terdapat di Laggoppo Desa Massangkae. Pappalimbang umumnya istirahat atau pulang kerumahnya sekitar pukul 22.00.

Meskipun mereka sudah pulang kerumahnya istirahat, namun mereka tetap beroperasi ketika ada masyarakat yang membutuhkanya. Kadang ada masyarakat yang ingin ke Kabupaten Sinjai pada malam hari atau masyarakat Laggoppo Desa Massangkae yang pulang larut malam dan sudah tidak ada pappalimbang, para pengguna ini tinggal menghubungi pappalimbang langganannya.

Pappalimbang juga menerima jasa rental. Biasanya mereka dirental oleh Nelayan pa'meng. Nelayan pa'meng ini masih menggunakan sistem kekerabatan dalam memilih pappalimbang untuk dirental. Biasanya nelayan pa'meng berangkat 5-10 orang dan nelayan pa'meng ini biasanya memancing ikan dekat dari perairan laut selama 2-3 malam dilaut memancing ikan.

\section{Kehidupan Sosial Ekonomi \\ Pappalimbang di Muara Sungai Tangka}

Bentuk umum dari proses sosial adalah interaksi sosial. Oleh karena itu, interaksi sosial merupakan syarat utama terjadinya 
aktivitas-aktivitas sosial. Interaksi sosial dapat diartikan sebagai hubunganhubungan sosial yang dinamis. Hubungan sosial yang dimaksud dapat berupa hubungan antara individu yang satu dengan individu lainnya, antara kelompok yang satu dengan kelompok lainnya, maupun antara kelompok dengan individu. (Ani Sri Rahayu, 2016)

Kehidupan sosial pappalimbang di Muara Sungai Tangka cenderung dipengaruhi oleh kehidupan ekonomi mereka. Dalam aktivitas-aktivitas kesehariannya dalam bekerja, mereka selalu menjalin interaksi dengan masyarakat. Mereka memiliki waktu yang sangat mudah untuk berinteraksi dengan masyarakat karena pekerjaan mereka atau profesinya yang bergantung kepada masyarakat. Bukan hanya dengan masyarakat mereka juga berinteraksi dengan sesama pappalimbang.

Proses interaksi yang mengarah pada persatuan sehingga terbentuk kerja sama diantara mereka. Kerja sama merupakan suatu bentuk interaksi sosial antara orangorang atau kelompok-kelompok, yang saling membantu untuk mencapai tujuan bersama. (Ani Sri Rahayu, 2016) Melalui interaksi-interaksi yang mereka lakukan sehingga kemudian melahirkan rasa kebersamaan dan persaudaraan. Kebersamaan inilah yang menjadikan mereka untuk saling membantu ketika ada diantara mereka yang terkena musibah.

Pappalimbang di Muara Sungai Tangka mempunyai hubungan sosial yang baik antar sesama pappalimbang karena adanya rasa senasib sepenanggungan diantara mereka. Hal itu terlihat saat mereka bekerja, dimana antara pappalimbang yang satu dengan yang lainnya saling membantu dalam berbagai hal. Dimana ketika salah satu dari mereka mengalami kesusahan atau kendala, pappalimbang yang lain membantunya. seperti ketika mengalami kendala pada perahunya. tidak hanya itu, mereka juga saling berbagi satu sama lain, seperti ketika perahu mereka sandar, pappalimbang yang tidak punya rokok, temannya yang memberikan dan seperti pula ketika pappalimbang punya kue atau makanan mereka menawarkan dan memberikan temannya.

Interaksi sosial pappalimbang dapat pula dilihat dari mereka yang cukup ramah dan dekat dengan penumpang. Agar mendapatkan penumpang, pappalimbang menawarkan jasanya dengan cara meneriaki secara sopan dan respon penumpangnyapun baik. Pappalimbang juga kerap bercanda dengan penumpangnya ketika perahu mereka sandar, seperti bapak Albert seorang pappalimbang, beliau sering melucu dengan penjual ikan di PPI Lappa (pusat pendaratan ikan).

Aktifitas keseharian papalimbang selalu berinterksi. Ketika berada di dermaga atau di PPI Lappa menunggu, mereka mengisi kekosongannya dengan cerita-cerita lepas sesama pappalimbang sambil menunggu penumpang, bahkan mereka biasa turun dari perahunya hanya untuk cerita-cerita lepas dengan tukang ojek yang ada baik di Dermaga Cappa Ujung maupun yang di PPI Lappa. kadang pula masyarakat sekitar yang naik diperahu pappalimbag untuk cerita-cerita.

Interaksi sosial bukan hanya secara langsung melainkan juga secara tidak langsung yakni melalui handphone. penumpang yang memiliki langganan biasanya menelpon pappalimbang untuk dijemput atau biasa ada yang pulang larut malam dari Kabupaten Sinjai mereka menghubungi pappalimbang. Pappalimbangpun senangtiasa menjemput masyarakat Laggoppo Desa Massangkae yang pulang larut malam dari Kabupaten Sinjai.

Bentuk Kehidupan sosial pappalimbang dengan pengguna jasa ini tidak hanya melalui interaksi melainkan juga dalam 
menolong. Dimana mereka membantu menaikkan dan menurunkan barang penumpang yang memiliki barang bawaan yang banyak. Bahkan kadang pappalimbang lainpun ikut terlibat membantu mengangkat barang penumpang temannya. Mereka juga membantu penumpang yang tidak bisa atau mengalami kesusahan ketika naik perahu biasanya mereka mengulurkan tangan atau mengambilkan tangga yang telah disediakan oleh pappalimbang. Pappalimbang juga kadang menunggu ketika penumpang mereka ada keperluan atau ada yang ditunggu. Dari cara mereka memperlakukan penumpangnya menunjukkan bahwa mereka mimiliki jiwa sosial yang tinggi.

Saling percaya antara pappalimbang dengan penumpang dapat kita lihat dari cara mereka membayar tarif penyeberangan. Dimana pappalimbang telah menyediakan tempat uang untuk pembayaran yang terletak diujung perahu sehingga pappalimbang tidak perlu keluar dari kemudinya atau penumpang yang ke kemudi pappalimbang. ketika uang penumpang lebih, penumpang itu sendiri yang mengambil kembaliannya pada tempat uang yang telah disediakan oleh pappalimbang. kecuali jika tidak ada, baru penumpang membayarnya langsung di pappalimbang atau pappalimbang yang ke penumpang. Selain itu, Saling percaya antara pappalimbang dengan pengguna dapat kita lihat ketika pengguna jasa pappalimbang menitipkan barang kepada pappalimbang untuk dikirim. Mereka yang menggunakan jasa ini sudah mempercayai pappalimbang sebagai jasa pengiriman barang. Seperti ketika salah satu ibu-ibu yang berada di PPI Lappa menitipkan ikan kepada pappalimbang untuk di kirim kepada keluarganya di Laggoppo Desa Massangkae.

Pengguna jasa pappalimbang juga memanfaatkan pappalimbang sebagai jasa untuk membeli tabung gas. Karena di
Laggoppo Desa Massangkae tidak ada yang menjual tabung gas, maka masyarakat Laggoppo menggunakan jasa pappalimbang. untuk membeli tabung gas. Mereka biasanya hanya memberikan uang pembeli tabung gas dan ongkosnya kepada pappalimbang tanpa harus mereka ikut berangkat

Sistem langganan yang mereka pakai juga menghindarkan mereka dari konflik sosial atau konflik penumpang. dari sistem langanan ini, pappalimbang tidak pernah mempermasalahkan soal penumpang karena mereka saling tahu dan sudah saling kenal langganan. Begitupun untuk mendapatkan penumpang diluar dari langganan, mereka tidak pernah memperebutkan. Mereka hanya menawarkan diri atau didatangi sendiri.

Dalam stratifikasi sosial, pappalimbang yang berada pada kelas atas yaitu mereka yang memiliki pekerjaan sampingan dan dibantu oleh keluarganya. Untuk kelas menengah, yaitu mereka yang menjadikan pappalimbang sebagai pekerjaan utama dan dibantu oleh keluarganya. Sedangkan untuk kelas bawah, dimana mereka yang menjadikan pappalimbang pekerjaan utama dan tanpa bantuan dari keluarganya . Jumlah anggota kelas menegah lebih dominan dibandingkan dengan kelas atas dan kelas bawah.

Stratifikasi sosial pappalimbang di Muara Sungai Tangka cenderung ditentukan oleh pekerjaan dan penghasilan yang diperoleh serta dilihat pula dari sandang dan papan. Sedangkan untuk pendidikan cenderung kurang menentukan seseorang untuk bisa masuk dalam kategori kelas atas, karena rata-rata pendidikan mereka adalah pendidikan SD atau tidak berpendidikan SD. Dengan tingkatan kelas sosial pappalimbang kurang ditentukan oleh pendidikan, tetapi ditentukan oleh pekerjaan dan penghasilannya.

Peghasilan mereka ditentukan oleh banyaknya penumpang yang mereka 
dapatkan, semakin banyak penumpang yang mereka dapatkan maka semakin banyak pula penghasilan yang mereka dapatkan begitupun sebaliknya ketika mereka sedikit mendapatkan penumpang maka sedikit pula penghasilannya. Penumpang menjadi modal mereka untuk mendapatkan penghasilan Sehingga dalam pemenuhan kebutuhan hidupnya mereka dituntut untuk giat bekerja.

Penghasilan pappalimbang kerja santai dengan pappalimbang kerja keras tentu berbeda, penghasilan pappalimbang kerja santai hanya di kisaran Rp.50.000 hal ini karena jumlah jam kerjanya. Pikirnya mereka hanya untuk pembeli rokok dan merasa tidak enak kalau hanya dirumah terus. Hal ini juga didasari Karena sudah ada tambahan penghasilan dari anaknya yang kerja. sedangkan pappalimbang kerja keras tentunya penghasilannya lebih banyak dibanding dengan kerja santai. Hal ini dikarenakan mereka sebagai penghasilan utama dan pappalimbang kerja keras inilah yang kerja mulai subuh sampai malam hari. Penghasilannya dikisaran Rp.100.000.

Penghasilan pappalimbang tidak hanya mereka dapatkan melalui penyeberangan dari Lagoppo Desa Massangkae ke Kabupaten Sinjai melainkan mereka juga merentalkan perahunya ke Pulau Sembilan bagi yang ingin memancing, untuk tarifnya ditentukan berdasarkan tawar menawar antara pappalimbang dengan pemancing. Tarifnya biasanya Rp. 500.000 satu hati. Selain itu, ada beberapa yang mencari kerja sampingan untuk mendapatkan penghasil tambahan. Seperti jadi petani, kerja empang dan buruh bangunan.

Untuk memenuhi kebutuhan dan keperluan harianya, pappalimbang bekerja secara kolektif. Artinya bukan hanya mereka sebagai kepala rumah tangga yang bekerja mencari nafkah melainkan mereka juga dibantu oleh istri dan anaknya. Kerja secara kolektif inilah merupakan bentuk strategi mereka untuk bertahan hidup sebab penghasilan dari pappalimbang belum bisa diandalkan untuk menutupi kebutuhan ekonominya sehingga mereka dibantu oleh istrinya untuk menambah pemasukan ekonomi keluarga. Biasanya istrinya berjualan ikan di PPI Lappa sedangkan anaknya pergi melaut.

$$
\text { Rata-rata anak }
$$

pappaimbang pendidikannnya hanya sampai SMP, hal ini dikarenakan ketidak sanggupaan orang tuanya untuk melanjutkan pendidikan anaknya. Penghasilan yang tidak menentu dan kecilnya penghasilannya menjadi kendala mereka untuk menyekolahkan anaknya. Pola pikir merekakapun sebagai orang tua hanya ingin anak mereka segera bekerja dan membantu orang tuanya. Sebagai anak pappaimbang yang hanya perpendidikan SMP, kebanyakan mereka melaut mencari ikan.

Pembangunan ekonomi membutuhkan jasa angkutan yang cukup serta memadai. Tanpa adanya transportasi sebagai sarana penunjang tidak dapat diharapkan tercapainya hasil memuaskan dalam usaha pengembangan ekonomi suatu Negara. Untuk tiap tingkatan perkembangan ekonomi diperlukan kapasitas angkutan yang optimal. (M Nur Nasution, 2004)

Keberadaan pappalimbang di Muara Sungai Tangka memberikan dampak terhadap perekonomian di Kabupaten Sinjai. dimana dengan keberadaanya memperlancar perekonomian di Kabupaten Sinjai. Dengan keberadaan pappalimbang maka aktivitas jual beli di PPI Lappa menjadi meningkat. Selain masyarakat Kabupaten Sinjai yang melakukan transaksi jual beli di PPI Lappa, adanya pappalimbang membuat masyarakat Laggoppo Desa Massangkae dan masyarakat Desa Awang Tangka ikut pula terlibat dalam aktivitas ini. masyarakat Laggoppo Desa Massangkae Kabupaten Bone dan masyarakat Desa Awang Tangka lebih memilih berbelanja atau berjualan di Kabupaten Sinjai karna alasan lebih dekat 
dibandingkan dengan Kabupaten Bone (Haerianty Rezki Sani, Amirullah, 2018). selain itu, PPI Lappa juga ramai di kunjungi oleh masyarakat sehingga menjadi pilihan mereka untuk berjualan. Sedangkan untuk masyarakat Desa Awang Tangka mereka memilih beli ikan di PPI Lappa karena murah sehingga mereka bisa untung banyak ketika dijual kembali.

\section{E. Kesimpulan}

Nelayan Adanya pappalimbang di Muara Sungai Tangka tidak terlepas dari kebutuhan masyarakat Laggoppo Desa Massangkae Kabu terhadap Kabupaten Sinjai. Masyarakat Laggoppo Desa Massangkae menjadikan Muara Sungai Tangka sebagai jalur Alternatif menuju ke Kabupaten Sinjai. Masyarakat memilih pappalimbang dengan alasan jarak tempuh yang lebih dekat dibanding jalan darat. Selain itu, munculnya pappalimbang di Muara Sungai Tangka juga dipengaruhi oleh faktor geografis. Dimana Muara Sungai Tangka yang berbatasan langsung antara Laggoppo Desa Massangkae Kab dengan ibu kota Kabupaten Sinjai yaitu Kelurahan Lappa Kecamatan Sinjai Utara di memanfaatkan oleh masyarakat sekitar untuk mendapatkan pekerjaan.

Perkembangan pappalimbang di Muara Sungai Tangka yaitu berkembangnya teknologi modern. Pappalimbang yang awalnya menggunakan sampang dengan tenaga manusia kemudian beralih dengan menggunakan tenaga mesin. Selama menggunakan mesin sudah ada tiga jenis perahu yang digunakan yaitu jarangka, katinting, dan jolloro. Perkembangan teknologi informasi juga mempengaruhi pappalimbang yaitu dimana pappalimbang juga sudah menggunakan Handphone.

Kehidupan sosial ekonomi pappalimbang di Muara Sungai Tangka adalah saling membantu dan memiliki rasa solidaritas yang tinggi. Aktivitas-aktivitas kesehariannya dalam bekerja selalu berinteraksi baik dengan sesama pappalimbang maupun dengan masyarakat sekitar. Sistem langganan menghindarkan mereka dari konflik penumpang. Penghasilan pappalimbang dalam sehari tidak menentu tergantung jumlah penumpang yang mereka dapatkan.

\section{DAFTAR PUSTAKA}

Agus, 2018. Wawancara di PPI Lappa Kabupaten Sinjai [interview] (20 Oktober 2018)

Amirullah (2017) 'Komunitas Nelayan

Laggoppo di Kabupaten Bone (1972-2010)', Pattingalloang, 4(2), pp. 1-10.

Badan Pusat Statistik. 2016. Kecamatan Kajuara Dalam Angka 2016. Bone: Badan Pusat Statistik Kabupaten Bone

Khisty, C Jotin, B Kent Lall. 2003. Dasardasar Rekayasa Transportasi. Jakarta: Penerbit Erlangga

Fajar, 2018. Wawancara di PPI Lappa Kabupaten Sinjai [interview] (15 Oktober 2018)

Gunawan, Herry. 2014. Pengantar Transportasi dan Logistik. Jakarta: RajaGrafindo Persada.

Haya, 2018. Wawancara di Laggoppo Desa Massangkae [interview] (12 Oktober 2018)

Hamid, Rahman, Muhammad Saleh Majid, 2011. Pengantar Ilmu Sejarah. Makassar: Ombak

Haerianty Rezki Sani, Amirullah, A. (2018) 'Penetrasi Nelayan Tradisional Panaikang 1955-1970',

Pattingalloang, 5(Januari-April), pp. 87-100. doi: Jurnal Pattingalloang.

Hafid, Muh Yusun, Pananrangi Hamid, Syarir Kila, dan Ansar. 1996. Pola Pemukiman dan Kehidupan Sosial Ekonomi Masyarakat Bajou Daerah Sulawesi Selatan. Sulawesi Selatan:

Bagian Proyek Pengkajian dan Pembinaan Nilai-Nilai Budaya Sulawesi Selatan.

Kantor Desa Massangkae. 2016. Desa Massangkae Dalam Tahun 2016. Desa Massangkae: Data Base Desa Massangkae 
Kahar, 2018. Wawancara di PPI Lappa

Kabupaten Sinjai [interview] (12

Oktober 2018)

Rahayu, Ani Sri. 2016. ISBD IImu Sosial \&

Budaya Dasar. Jakarta: Bumi

Aksara

Reni, 2018. Wawancara di PPI Lappa

Kabupaten Sinjai [interview] (12

Oktober 2018)

Bapak Ramang, 2018. Wawancara di PPI Lappa Kabupaten Sinjai [interview] (20 Oktober 2018)

S. Mulyadi. 2014. Ekonomi Sumber Dya Manusia. Jakarta: RajaGrafindo Persada. 